\title{
Discordant Monozygotic Twins for Macrocephaly-Capillary Malformation
}

\section{Damien Lederer, ${ }^{1,2 *}$ Katrina Rack, ${ }^{1}$ Sébastien Boulanger, ${ }^{1}$ Oreste Battisti, ${ }^{3}$ and Christine Verellen-Dumoulin ${ }^{1}$}

\author{
${ }^{1}$ Center For Human Genetics, IPG, Charleroi [Gosselies], Belgium \\ ${ }^{2}$ Department of Paediatrics, Cliniques Universitaires Saint-Luc, UCLouvain Bruxelles, Belgium \\ ${ }^{3}$ Centre Hospitalier Universitaire, Paediatrics, Liège, Belgium
}

Manuscript Received: 4 August 2011; Manuscript Accepted: 3 March 2012

\section{TO THE EDITOR:}

Macrocephaly-cutis marmorata telangiectatica congenita (MIM $602501)$ is a rare multiple congenital abnormalities/intellectual disability and overgrowth disorder, comprising macrocephaly, cutis marmorata, midline facial capillary malformation often involving the lips and/or philtrum, syndactyly, hemihyperplasia, central nervous system (CNS) abnormalities, and developmental delay. First described in 1997 [Clayton-Smith et al., 1997; Moore et al., 1997], this syndrome was subsequently named macrocephalycapillary malformation (M-CM) by Toriello and Mulliken [2007]. Here, we report on the first case of discordant monozygotic twins with $\mathrm{M}-\mathrm{CM}$, and the proband has unique features.

The proband is the fourth of five girls from second-degree consanguineous Turkish parents. An elder sister had camptodactyly, truncal hypotonia, and labia majora/clitoral hypertrophy. She died at 11 months with encephalopathy of unknown etiology. The proband was born at 35 weeks of gestation by caesarean for macrocephaly and fetal distress after an uneventful monochorial/ monoamniotic twin pregnancy. Birth weight was 2,470 g (90th centile on monozygotic twin growth chart, 50th centile on singleton growth chart), birth length was $46 \mathrm{~cm}$ (50th centile on singleton growth chart), and occipito-frontal circumference (OFC) was $35.5 \mathrm{~cm}$ ( $>90$ th centile on singleton growth chart). APGAR scores were 8 at $1 \mathrm{~min}$ and 10 at $5 \mathrm{~min}$. Clinical examination showed frontal bossing, nasal, and frontal capillary malformations, intermittent right eye strabismus, hypertelorism, right epicanthus, long philtrum, vaulted palate, full lips, deep palmar creases, gap between first and second toes, axial and peripheral hypotonia, generalized capillary malformation that faded with age, and thick subcutaneous tissue (Fig. 1). During the neonatal period, profound episodes of hypoglycemia required treatment with intra-venous glucose perfusion until the 4th day of life. Metabolic investigations, including plasma and urine amino acids, urine organic acids, blood lactate, ammonia, and insulin, were normal both at the time of hypoglycemia episodes and when controlled at 8 months of age.

A transfontanellar ultrasound in the neonatal period showed thalamic and periventricular calcifications and mild ventricular hydrocephaly. Auditory and visual evoked potentials were normal.

\section{How to Cite this Article:}

Lederer D, Rack K, Boulanger S, Battisti O, Verellen-Dumoulin C. 2012. Discordant monozygotic twins for macrocephalycapillary malformation.

Am J Med Genet Part A 158A:1509-1511.

Her OFC curves increased disproportionately with age. A CT-Scan performed at 6 months showed bilateral hydrocephaly (Evans' index 0.32), but no posterior fossa abnormalities. A brain MRI at 7 months showed cerebellar tonsillar herniation $(\mathrm{CTH})$, hydrocephaly, and indirect signs of cerebral hypertension (hydrocephaly with enlarged subarachnoid pericerebral space). Ventricular shunting at 11 months (Fig. 1C) improved both the OFC, which remained at $51 \mathrm{~cm}$ until death, and psychomotor development.

At 19 months, she had tonic-clonic movements of right upper limb accompanied by crying and cutaneous flushing. An EEG showed slow basal rhythm and paroxysm on the left part of her brain. There was no seizure recurrence on Valproate therapy. Chest X-ray showed 11 pairs of ribs. There were no other osseous abnormalities. Thermoregulation instability appeared after the first year of life with a usual temperature between 38 and $39^{\circ} \mathrm{C}$. Feeding difficulties were experienced throughout life and major milestones were delayed (unable to sit alone, no words at 17 months). She smiled easily and had good interactive contact. She died at 23 months from disseminated intravascular coagulation following a common respiratory viral infection. Autopsy was refused by the parents.

\footnotetext{
${ }^{*}$ Correspondence to:
}

Dr. Damien Lederer, Center for Human Genetics, IPG, avenue Georges Lemaitre 25, 6041 Charleroi (Gosselies), Belgium.

E-mail: damien.lederer@ipg.be

Article first published online in Wiley Online Library

(wileyonlinelibrary.com): 14 May 2012

DOI 10.1002/ajmg.a.35382 


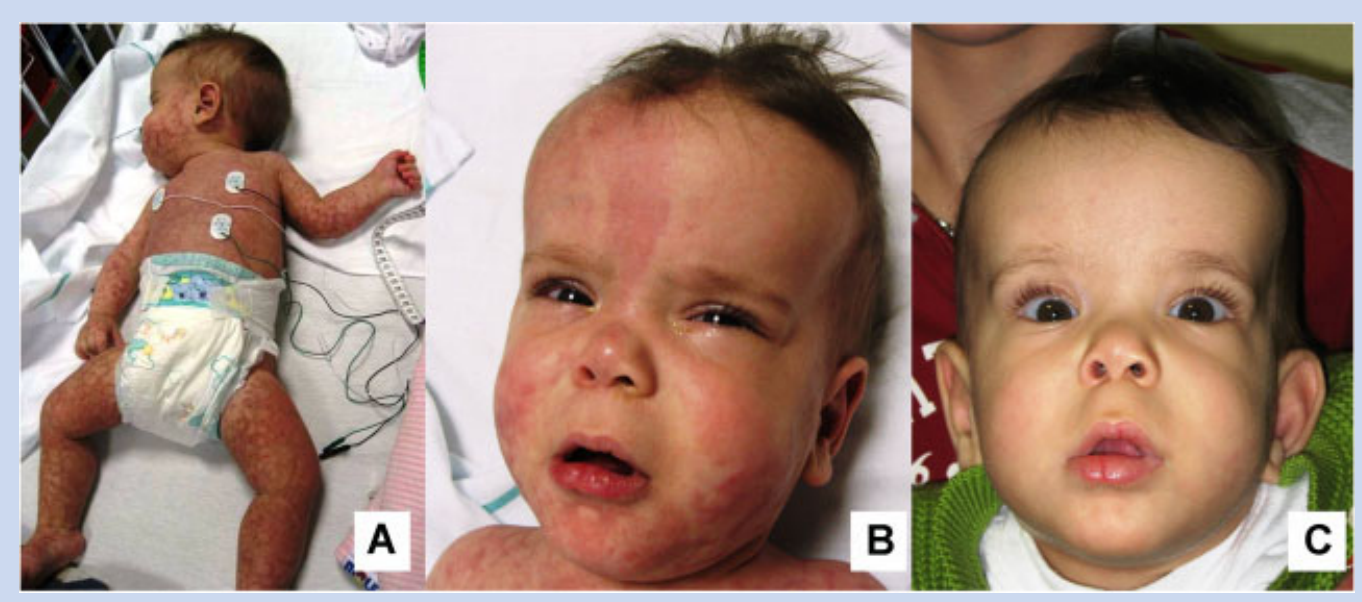

FIG. 1. A: Patient at 8 months. Note the generalized aspect of the capillary malformation. B: Patient at 10 months with frontal bossing, nasal, and frontal capillary malformations, hypertelorism, right epicanthus, long philtrum, full lips. C: Patient at 12 months. Note the fading of capillary malformation and the amelioration of hydrocephalic aspect after the ventricular shunt.

Her monozygotic twin was clinically normal, birth weight was $2,270 \mathrm{~g}$ (75th centile on monozygotic twin growth chart, 25th centile on singleton growth chart), length was $44 \mathrm{~cm}$ (10-25th centile on singleton growth chart), head circumference was $32.5 \mathrm{~cm}$ (50-75th centile on singleton growth chart).

Major and minor criteria have been proposed for the diagnosis of M-CM. For Franceschini et al. [2000] a M-CM diagnosis requires macrocephaly and at least two other manifestations such as overgrowth, cutis marmorata/capillary malformation, angiomata, syndactyly, or asymmetry. Whereas Robertson et al. [2000], suggest that congenital macrocephaly and cutis marmorata/capillary malformation are obligatory plus at least 4 of the following findings: neonatal hypotonia, developmental delay, connective tissue defect, frontal bossing, midline facial nevus flammeus, cutaneous toe syndactyly, segmental overgrowth, and hydrocephalus. In a review of 75 cases of M-CM, Lapunzina et al. [2004] classified the manifestations of macrocephaly, cutis marmorata telangiectatica/ capillary malformation, and hemangioma as very frequent $(>75 \%$ of cases) whilst developmental delay, hydrocephalus, frontal bossing, and thick subcutaneous tissue are frequent $(25-75 \%$ of cases).

Given that this patient had macrocephaly, capillary malformation, neonatal hypotonia, developmental delay, frontal bossing, midline facial nevus flammeus, and hydrocephaly, she fulfils both proposed criteria for M-CM. She also fulfils the criteria recently suggested by Martinez-Glez et al. [2010]. She did not have body asymmetry, digital polydactyly or syndactyly, hyperelastic skin or joint hyperlaxity. Even though typical of M-CM, these features are not constant findings in M-CM [Lapunzina et al., 2004]. Moreover, the face of the proband is similar to other cases of M-CM with full lips and central facial capillary malformations. The evolution of capillary malformations, which faded with age, is also very typical. Cerebellar tonsillar herniation appears to be very common in $\mathrm{M}-\mathrm{CM}$ and, as in our case, is frequently acquired with rapid progression [Conway et al., 2007; Papetti et al., 2011]. This case highlights the importance of neuroimaging follow-up of children with $\mathrm{M}-\mathrm{CM}$ due to the rapid evolution of $\mathrm{CTH}$. The proband also has unique features such as thermoregulation dysfunction and intracerebral calcifications, although for the latter we cannot exclude an ischemic event due to fetal distress.

To date, 132 cases of M-CM have been reported, of which the etiology remains unknown. Only three cases were associated with cytogenetic abnormalities involving skin sex chromosome mosaicism, translocation $\mathrm{t}(2 ; 17)(\mathrm{p} 11 ; \mathrm{p} 13)$, and 16q deletion, and two individuals were born to consanguineous parents [Lapunzina et al., 2004]. The karyotype of this case, performed on two tissues (peripheral blood lymphocytes and fibroblasts) was normal $(46, \mathrm{XX})$ as was array-CGH analysis on lymphocyte DNA (Agilent platform, 44k).

All reported cases were sporadic and none involved a discordant monozygotic twin (DMT). There are, however, two cases of discordant dizygotic twins with a healthy female and an affected boy [Yano and Watanabe, 2001; Conway et al., 2007]. A monozygotic twin test performed twice on two independent saliva samples confirms that the proband and her twin sister were monozygotic (short tandem repeats analyses kit PowerPlex 16 by Promega). This case is therefore the first reported monozygotic twin with M-CM.

Proteus syndrome (OMIM 176920) shares similarities with M-CM. Recently, a mosaic activating mutation was discovered in AKT1 (OMIM 164730) in individuals with Proteus syndrome [Lindhurst et al., 2011]. Using Sanger sequencing, we were unable to find this $A K T 1$ mutation in DNA from either fibroblasts or peripheral blood lymphocytes.

The discordant phenotype of monozygotic twins is generally of nongenetic etiology. Infection screening was not performed on the proband, but the mother had positive CMV, rubella and toxoplasmosis antibody titers prior to pregnancy, and there were no serologic signs of secondary CMV infection during the pregnancy. 
Where DMT is of genetic origin, its variable expression can be explained by the following mechanisms. The first assumes, in the case of females, that the syndrome is X-linked and that expression, or absence, of the phenotype results from skewed X-inactivation. However, there is no evidence to suggest that $\mathrm{M}-\mathrm{CM}$ is X-linked since the incidence of reported cases is equivalent in males and females (73 males $(55 \%)$ vs. 59 females $(45 \%))$. Furthermore, $\mathrm{X}$-inactivation profiling of the proband and her twin showed normal patterns (respectively $42 / 58$ and 39/61). An X-inactivation pattern was determined by PCR amplification of the CAG repeat in exon 1 of the androgen receptor gene before and after DNA digestion with $H p a I I$ and $C f o I$. The second mechanism to consider is differential methylation patterns of imprinted genes as seen in DMT for Beckwith-Wiedemann syndrome [Tierling et al., 2011]. A third mechanism to explain DMT is a post-zygotic mutation event, leading to somatic mosaicism in the affected twin. There was no evidence of chromosome mosaicism in the affected twin, although we cannot fully exclude this possibility due to the limited number of tissue samples examined by karyotype and aCGH. Nor can we exclude the occurrence of a point mutation or methylation mosaicism in this case.

Patchy cutaneous vascular malformations [Wright et al., 2008], body asymmetry, and general variability of clinical findings commonly seen in macrocephaly-capillary malformation are all manifestations that are consistent with a potential role for somatic mosaicism in this disorder [Clayton-Smith et al., 1997; Gripp et al., 2009], and this case reinforces this hypothesis.

\section{ACKNOWLEDGMENTS}

We would like to thank the "Fonds Marguerite-Marie Delacroix" for the research grant provided to Lederer D.

\section{REFERENCES}

Clayton-Smith J, Kerr B, Brunner H, Tranebjaerg L, Magee A, Hennekam RCM, Mueller RF, Brueton L, Super M, Steen-Johnsen J, Donnai D. 1997. Macrocephaly with cutis marmorata, haemangioma and syndactyly-A distinctive overgrowth syndrome. Clin Dysmorphol 6:291-302.

Conway RL, Pressman BD, Dobyns WB, Danielpour M, Lee J, Sanchez-Lara PA, Butler MG, Zackai E, Campbell L, Saitta SC, Clericuzio CL, Milunsky JM, Hoyme HE, Shieh J, Moeschler JB, Crandall B, Lauzon JL, Viskochil DH, Harding B, Graham JM Jr. 2007. Neuroimaging findings in macrocephaly capillary malformation: A longitudinal study of 17 patients. Am J Med Genet Part A 143:2981-3008.

Franceschini P, Licata D, Di Cara G, Guala A, Franceschini D, Genitori L. 2000. Macrocephaly-cutis marmorata telangiectatica congenita without cutis marmorata? Am J Med Genet 90:265-269.
Gripp KW, Hopkins E, Vinkler C, Lev D, Malinger G, Lerman-Sagie T, Dobyns WB. 2009. Significant overlap and possible identity of macrocephaly capillary malformation and megalencephaly polymicrogyriapolydactyly hydrocephalus syndrome. Am J Med Genet Part A 149: 868-876.

Lapunzina P, Gairi A, Delicado A, Angeles M, de Torres L, Goma A, Navia M, Lopez Pajares I. 2004. Macrocephaly-cutis marmorata telangiectatica congenita: Report of six new patients and a review. Am J Med Genet Part A 130:45-51.

Lindhurst MJ, Sapp JC, Teer JK, Johnston JJ, Finn EM, Peters K, Turner J, Cannons JL, Bick D, Blakemore L, Blumhorst C, Brockmann K, Calder P, Cherman N, Deardorff MA, Everman DB, Golas G, Greenstein RM, Kato BM, Keppler-Noreuil KM, Kuznetsov SA, Miyamoto RT, Newman K, Ng D, O’Brien K, Rothenberg S, Schwartzentruber DJ, Singhal V, Tirabosco R, Upton J, Wientroub S, Zackai EH, Hoag K, Whitewood-Neal T, Robey PG, Schwartzberg PL, Darling TN, Tosi LL, Mullikin JC, Biesecker LG. 2011. A mosaic activating mutation in AKT1 associated with the Proteus syndrome. N Engl J Med. 365: 611-619 (Epub 2011 Jul 27).

Martinez-Glez V, Romanelli V, Mori MA, Gracia R, Segovia M, GonzalesMeneses A, Lopez-Gutierrez JC, Gean E, Martorell L, Lapunzina P. 2010. Macrocephaly-capillary malformation: Analysis of 13 patients and review of the diagnostic criteria. Am J Med Genet Part A 152: 3101-3106.

Moore CA, Toriello HV, Abuelo DN, Bull MJ, Curry C, Hall BD, Higgins JV, Stevens CA, Twersky S, Weksberg R, Dobyns WB. 1997. Macrocephaly-cutis marmorata telangiectatica congenita: A distinct disorder with developmental delay and connective tissue abnormalities. Am J Med Genet 70:67-73.

Papetti L, Tarani L, Nicita F, Ruggieri M, Mattiucci C, Mancini F, Ursitti F, Spalice A. 2011. Macrocephaly-capillary malformation syndrome: Description of a case and review of clinical diagnostic criteria. Brain Dev 34:143-147.

Robertson SP, Gattas M, Rogers M, Adès LC. 2000. Macrocephaly-cutis marmorata telangiectatica congenita: Report of five patients and a review of the literature. Clin Dysmorphol 9:1-9.

Tierling S, Souren NY, Reither S, Zang KD, Meng-Hentschel J, Leitner D, Oehl-Jaschkowitz B, Walter J. 2011. DNA methylation studies on imprinted loci in a male monozygotic twin pair discordant for Becwith-Wiedemann syndrome. Clin Genet 79:546-553.

Toriello HV, Mulliken JB. 2007. Accurately renaming macrocephaly-cutis marmorata telangiectatica congenita (M-CMTC) as macrocephalycapillary malformation (M-CM). Am J Med Genet Part A 143:3009.

Wright DR, Frieden IJ, Orlow SJ, Shin HT, Chamlin S, Schaffer JV, Paller AS. 2008. The misnomer "macrocephaly-cutis marmorata telangiectatica congenita syndrome": Report of 12 new cases and support for revising the name to macrocephaly-capillary malformations. Arch Dermatol 145:287-2293.

Yano S, Watanabe Y. 2001. Association of arrhythmia and sudden death in macrocephaly-cutis marmorata telangiectatica congenita syndrome. Am J Med Genet 102:149-152. 